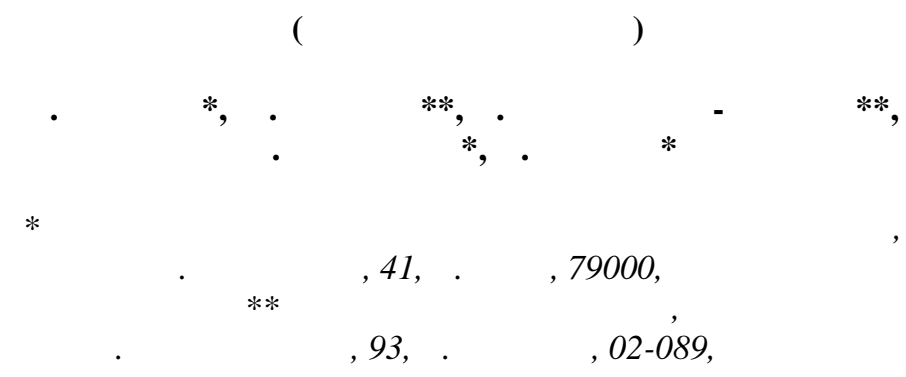

ро н лізов но головні літологічні х р ктеристики люві льної піщ но-гр війно-г лечникової товщі шостої тер си ністр (поверхні оєвої) поблизу м. мбір ьвівської обл. х р ктеризов но: текстурні елементи товщі, гр нулометричний т петрогр фічний скл д лювію, обк т ність гр війно-г лечникового м тері лу, орієнт цію г лечників тощо. підст ві отрим них результ тів літологічних досліджень реконструйов но умови седимент ції люві льної піщ ногр війно-г лечникової товщі шостої тер си ністр (поверхні оєвої) у р йоні м. мбір.

лючові слов : гр нулометричний скл д, петрогр фічний скл д, обк т ність, сортов ність, імбрик ція, б г торук вне русло, умови ос дон гром дження.

еред низки скл дних, ост точно не вирішених геоморфологічних, п леогеогр фічних проблем ередк рп ття, одне з чільних місць посід є пит ння формув ння, будови т к зв ної поверхні оєвої. о суті, з ч сів . ессейре, який першим ідентифікув в цю поверхню [24], ми м ло просунулись у вирішенні т ких ключових проблем: ч су, мех нізмів їі формув ння, поширення т н віть розуміння того, що т ке вл сне $є$ поверхня оєвої. м першовідкрив ч поверхні оєвої - . ессейре - ув ж в, що: “н підст ві вл сних досліджень виділяю у східному ередк рп тті дв головних рівні тер $c^{*}$ “верхній” і “нижній”. о “верхнього” рівня, який н зв в свого ч су “поверхнею оєвої”, з р ховую вододільні ділянки усіх головних рік” [24].

обто . ессейре розгляд в поверхню оєвої як групу гіпсометрично зближених між собою річкових тер с. д лі вчений висловив гіпотезу щодо мех нізмів формув ння поверхні оєвої: “ ередк рп тті річки пересув лися поступово у різних н прям х, омин ючи н копичені ними ж конуси винесення бо скеровув лись дрібними тектонічними рух ми. і річки формув ли у м'якому м тері лі лож широкі ерозійні поверхні і з сип ли їх потужною товщею гр війно-г лечникового м тері лу” [24].

н ступній публік ції, як вийшл 1938 р., . ессейре ще кцентов ніше з зн чив, що поверхню оєвої він розгляд в як групу гіпсометрично зближених між собою річкових тер с: “ дет льних досліджень ув ж ю, що до скл ду вододільних поверхонь може входити декільк н дзвич йно зближених між собою тер с. дн к виокремлення їх виявилось неможливим. ому обговорюв ні поверхні я охопив як один рівень, швидше як одну групу тер с, “верхнюю групу” [25].

* ут і д лі виділення н ше. - . иишин $m$ ін.

(C) цишин ., омбель ., льшевськ - ейберт . т ін., 2012 
нший зн ковий дослідник поверхні оєвої - . офштейн - 3 г лом поділяв погляди . ессейре н мех нізм формув ння поверхні оєвої, зокрем , він пис в: “ ністер, як і його к рп тські притоки, в меж х ередк рп ття не м в глибокої долини і мігрув в н обширному рівнинному просторі”. д лі “... ф ктичний м тері л свідчить про дост тньо повне вирівнюв ння не тільки люві льних, й підстелюючих корінних порід. им с мим підтверджується думк - ессейре про існув ння д вньої денуд ційної, бо точніше денуд ційно- кумулятивної, поверхні оєвої” [2].

. емедюк i . p вчук поділяли з пропонов ні . ессейре т . офштейном уявлення про мех нізм формув ння зг д ної поверхні [4-6]. дн к зі сторінок публік цій цих вторів, як i, до речі, з публік цій . офштейн , одноч сно зник ють ідеї уч сті в будові поверхні оєвої декількох гіпсометрично зближених між собою річкових тер с, прин ймні кцентов но про них не зг дується.

езульт ти б г торічних геолого-геоморфологічних досліджень, проведених у різних р йон х ередк рп ття $[12,14,16]$, підтверджують спостереження . ессейре в тій ч стині, де поверхня оєвої вигляд є як рівень, у якому об'єдн ні декільк гіпсометрично зближених тер с. дн к щодо пит нь про кількість цих тер с, їхнє поширення, ч с формув ння, т кож робот яких водотоків призвел до розвитку цієї системи теp c, об'єдн них нині у поверхню оєвої, то вони н р зі ост точно не вирішені. рештою, не зрозуміло як інтерпретув ти ці різновисотні тер си: як різновікові утворення, тобто тер си, які сьогодні об'єдн ні у т к зв ний рівень оєвої, бо як гіпсометрично відмінні блоки поверхні оєвої, що сформув лися вн слідок розвитку трив лих різномлітудних, можливо, й різнон прямлених тектонічних рухів, які й розбили н окремі блоки колись монолітну (одновікову) поверхню вирівнюв ння оєвої (шосту тер су)?

кл дність вирішення пост влених пит нь зумовлен , серед усього іншого, і тим, що ми дещо обмежені в з стосув нні методів досліджень. о суті, сьогодні головними метод ми досліджень річкових тер с, розвинених н вододіл х головних к рп тських приток ністр у ередк рп тті (поверхні оєвої), є морфометричний т стр тигр фічний. дн к щодо морфометричного критерію, то тер си ністр , його приток, у тому числі й поз долинні, які розт шов ні н вододіл х рік, не з вжди можн визн чити виокремивши їх з цим пок зником, т підр хув ти кількість. ро це, до речі, пис в . ессейре [25]. передк рп тській ч стині долини річки тер си м ють ухили в бік численних улоговин, бо н вП ки, здеформов ні тектонічними рух ми, головно, висхідного х р ктеру. огляду н це тер си подекуди “розщеплюються" н декільк “нових" тер с, невідомих для сусідніх ділянок долини, бо, н вп ки, злив ються в єдиний, пр ктично нероздільний, рівень. обто висоти тер с, їхні порядкові номери в меж х тектонічно скл дного ктивного р йону, яким $\epsilon$ ередк рп ття, з леж ть від 6 г тьох чинників, у тому числі й місцевих. ому проводити кореляцію тер с 3 їхньою висотою бо відносним розт шув нням тер сового рівня (порядковим номером) тут дуже скл дно, точність морфологічного методу у визн ченні кількості тер с в умов х долини ністр , н н ше перекон ння, $є$ невисокою.

тр тигр фічний метод досліджень річкових тер с у ередк рп тті грунтується, передусім, н стр тигр фічному розчленув нні т кореляції лесово-грунтових покривів тер с [14]. нші методи, як, н прикл д, біостр тигр фічні, н с мперед п леом л кологічні, мікротеріоф уністичні, які широко використовув лись під ч с досліджень відкл дів високих (н дк ньойонних) тер с ністр н подільському відтинку долини річки, його приток, і які д ли добрі м тері ли для впорядкув ння процесів ерозії, кумуляції н подільському відтинку долини ністр [1,7], у ередк рп тті пр ктично не вико- 
ристовув ли. е пов'яз но з тим, що пр ктично зовсім нем , прин ймні досі не зн йдено, решток флори, ф уни у відкл д х високих тер с ністр, його приток. одо покривних лесово-грунтових товщ тер с, які д ють добрі м тері ли для ідентифік ції теp c, визн чення ч су їхнього формув ння [14], то вони пог но збережені н вододіл х рік, тобто т м, де й поширен поверхня оєвої, бо не збережені вз г лі, тому м ють обмежене з стосув ння у вирішенні н мічених проблем.

цих умов х чи не єдиними перспективними, універс льними методом вирішення пит нь історії формув ння, будови поверхні оєвої є, н н ш погляд, літологічні дослідження люві льних товщ тер с поверхні оєвої. 3 незрозумілих для н с причин досі т кі дослідження у ередк рп тті пр ктично не проводили, бо проводили поверхово $[2,4-6]$.

еред літологічних досліджень люві льного м тері лу в світлі вирішув ної проблеми першочергово треб виконув ти комплексні н лізи його крупноул мкової фр кції: гр нулометрії, сортов ності, обк т ності, петрогр фічного скл ду, форми ул мків т їхньої орієнт ції. етодику т ких н лізів сьогодні добре опр цьов но [3, 8, 9, 11 , $13,17,18-23,26-28]$.

еоморфологічн будов р йону досліджень. озріз орг новичі 1 репрезентує будову відкл дів гіпсометрично н йвищого блок поверхні оєвої бо, ліпше ск з ти, гіпсометрично н йвищої тер си межиріччя тривігору- ністр, як р зом з трьом іншими тер с ми нині об'єдн н в поверхню оєвої. ер с розвинен н південному 3 ході межиріччя тривігору- ністр , у р йоні сіл чин - орчиновичі- орг новичівлівк . ут вон формує вузький вододіл ністр - тривігору (p. сениці) i сеницілинівки. 3 ході межиріччя, у р йоні сіл чин - орчиновичі, денн поверхня тер си витрим н в меж х 360-370 м, м ксимум - 381 м, що ст новить 60-70 м н д руслом тривігору і 50-60 м н д руслом ністр . околь тер си піднім ється н 45-50 м н д руслом тривігору і н 35-40 м н д руслом ністр .

озріз орг новичі 1 розт шов ний у дорожній виїмці, як тягнеться від сел н північ. розрізі відслонено лише верхніх 2,5 м товщі гр війно-г лечникового м тері лу. ижня ч ст люві льної товщі, її конт кт з корінними відкл д ми (цоколем) не відслонений. иходи корінних відкл дів (пісковиків, н копичення брил, в лунів пісковиків т силіцитів) можн поб чити поряд з розрізом, спустившись н 30-40 м униз по схилу. ереп д висот між виход ми н денну поверхню корінних порід і відслоненням лювію досяг є 5-6 м. г льн потужність гр війно-г лечникової товщі досяг є 5 м.

розрізі орг новичі $1 \mathrm{H}$ н лізи гр нулометричного, петрогр фічного скл ду ул мків ми відібр ли лише одну серію з трьох проб. роби відбир ли по вертик лі через кожні 0,5 м. м не вд лось відібр ти контрольну серію проб по л тер лі. е пов'яз но як із незн чними розмір ми відслонення, т к і зі скл дною текстурою товщі відкл дів, у якій лювій з ляг в здебільшого у вигляді м лопотужних лінз, ш рів (рис. 1).

л сне 3 цих лінз, ш рів неможливо було відібр ти серію проб по вертик лі й л теp лі. робу 1 ми відібр ли з глибини близько 60 см від покрівлі гр війно-г лечникової товщі - це яскр во вир жений горизонт льно ш рув тий ш р лювію потужністю 2025 см. роб 2 відібр н з глибини 119 см від покрівлі гр війно-г лечникової товщі, проб 3 з глибини $160 \mathrm{~cm}$.

роб 1 х р ктеризує відкл ди, що н леж ть до середньовідсортов них, оскільки 50,8 \% від з г льної м си ул мків проби предст влені середньо-, дрібно-, тонкоул мковим (піщ но-, леврито- глинистим) м тері лом. рупноул мков скл дов предст влен лише гр війними т г лечниковими зерн ми, в лунів нем вз г лі. петрогр - 
цишин, . омбель, . льшевськ - ейберт т ін.

фічним скл дом крупні ул мки предст влені лише пісковик ми т левроліт ми. ісковики світло-коричневі, коричневі, дрібнозернисті, ч сто леврито-дрібнозернисті, н межі з левроліт ми, з нерівним, головно р ковистим зл мом. левроліти з г лом схожі н пісковики 3 кольором, зл мом, відрізняються лише розміром зцементов них ул мків - скл дені зерн ми левритової розмірності. сто провести чітку межу між пісковик ми т левроліт ми дуже скл дно.
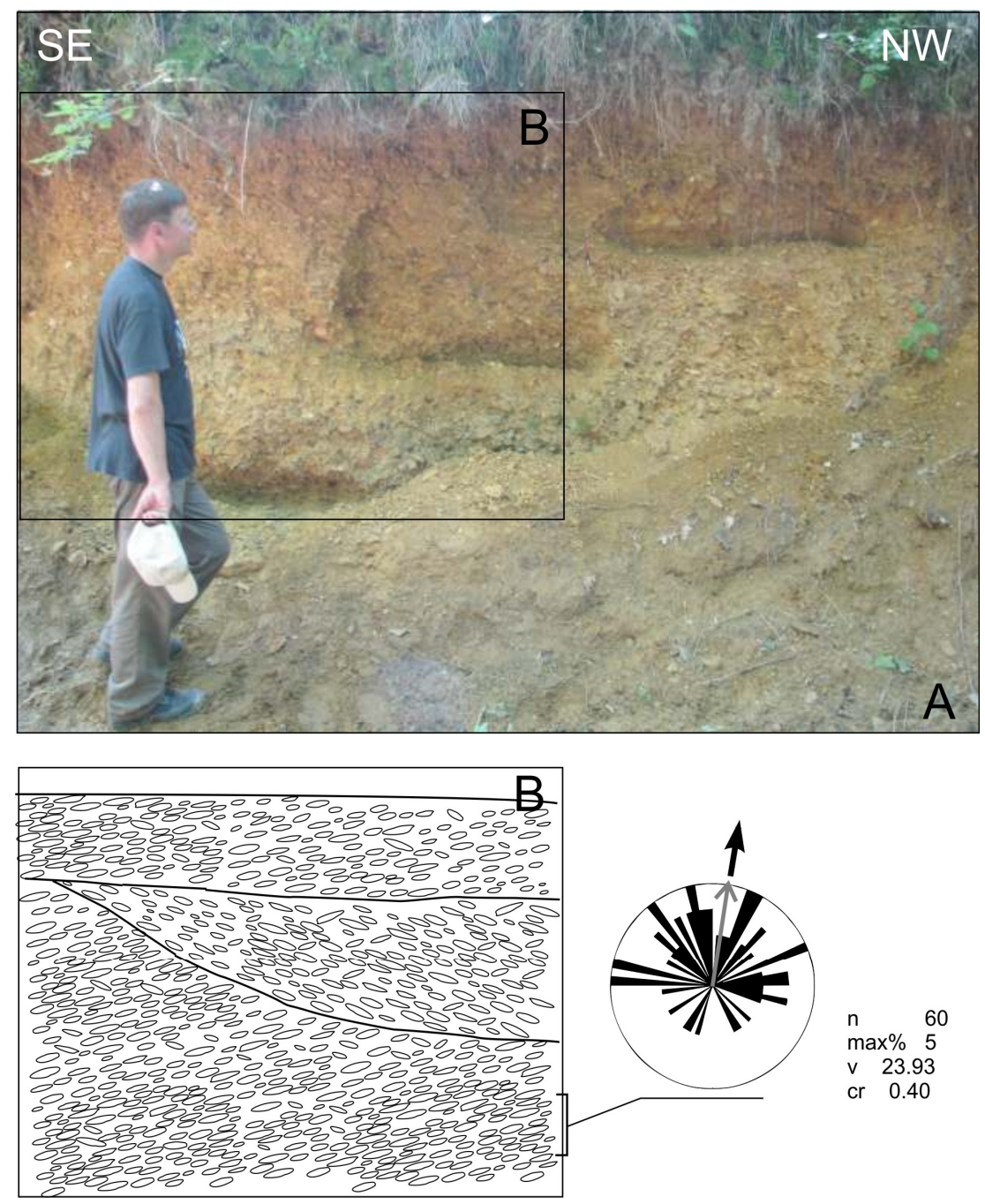

ис. 1. рофіль відслонення орг новичі 1 ( ) з інтерпрет цією текстурних елементів лювільної товщі ( ) т з роз ми-ді гр м ми і вектор ми з міряних імбрик цій гр вію. оризонти: 1 - корінні глини, піски, пісковики; 2 - піщ но-гр війно-г лечникового м тері лу; 3 - суглинків сірих з поодинокими гр війними зерн ми; 4 - суглинків темно-сірих, м йже чорних; 5 - в жких суглинків голубув то-сірого кольору; 6 - лесоподібних супісків. нше: $n$ - кількість з мірів імбрик ції; max \% - крок усереднення зимутів (через $\left.5^{\circ}\right) ; v$ - зимут вип дкового вектор ; $\mathrm{cr}$ - геометричн сум векторів, витрим них в одній лінії. 
p нулометричний скл д лювію розрізу орг новичі 1 м є т кий вигляд (т бл. 1).

блиця 1

езульт ти гр нулометричних н лізів лювію

\begin{tabular}{|c|c|c|c|c|c|c|}
\hline \multirow{3}{*}{\begin{tabular}{c}
\multicolumn{2}{c}{ озмір } \\
фр кцій, \\
мм
\end{tabular}} & \multicolumn{6}{|c|}{ езульт ти гр нулометричного н лізу відкл дів: } \\
\hline & \multicolumn{2}{|c|}{ роби 1} & \multicolumn{2}{|c|}{ роби 2} & \multicolumn{2}{|c|}{ роби 3} \\
\hline & 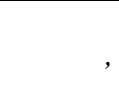 & 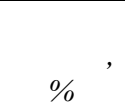 & $\begin{array}{cc}M & c \\
\phi p & \kappa ц і ̈ ̈, \\
\kappa 2\end{array}$ & $\begin{array}{c}\text { вміст } \\
\text { фр кцї̈, } \\
\%\end{array}$ & 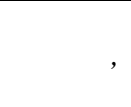 & $\begin{array}{c}\text { вміст } \\
\text { фр кцї̈, } \\
\%\end{array}$ \\
\hline он Д 40 & 2,2 & 4,4 & 5,9 & 11,8 & 1,7 & 3,4 \\
\hline 40-10 & 8,8 & 17,6 & 12,2 & 24,4 & 8,9 & 17,8 \\
\hline 10-2 & 13,6 & 27,2 & 11,7 & 23,4 & 14,3 & 28,6 \\
\hline енше 2 & 25,4 & 50,8 & 20,2 & 40,4 & 25,1 & 50,2 \\
\hline
\end{tabular}

р кція 40-10 мм н 90 \% від з г льної кількості ул мків скл ден левроліт ми, решт $(10 \%)$ - це дрібнозернисті пісковики.

р кція пон д 40 мм предст влен всього 11 ул мК ми, усі ул мки зі ст більною формою. петрогр фічому скл ді ул мків домінують левроліти (10 ул мків 3 11). ісковики дрібнозернисті, предст влені одним ул мком. еред ул мків фр кції домінують зерн розміром 75-95 мм по довгій осі.

роб 2 т кож репрезентує середньовідсортов ний лювій, одн к у ньому домінує крупноул мков скл дов , як досяг є 59,6 \% від з г льної м си ул мків проби. ередньо-, дрібно-, тонкоул мковий (піш но-, леврито- глинистий) м тері л $з$ йм є 40,4 \% від $з$ г льної м си ул мків проби.

рупноул мков скл дов предст влен лише левроліт ми т пісковик ми. еред ул мків розміром 40-10 мм до $94 \%$ від з г льної кількості предст влені світло-коричневими левроліт ми, до $5 \%$ - світло-сірими, білими левроліт ми, решт (близько $1 \%$ ) - пісковик ми.

л мків розміром пон д 40 мм н лічув лось 53, одн к 3 них 27 виявились неміцними, без ст більної форми. еред ул мків зі ст більною формою, яких було 26 зр зків, тр плялися: пісковик (один ул мок), середньозернистий, розміром до 140 мм по довгій осі, середньообк т ний т 24 х р ктерні для розрізу орг новичі 1 світло-коричневі левроліти.

тері л проби 3, як і проби 1, н лежить до середньовідсортов ного, у якому 50,2 \% від з г льної м си ул мків предст влено середньо-, дрібно-, тонкоул мковим (піщ но-, леврито- глинистим) м тері лом. рупноул мковий м тері л проби з йм є 49,8\% від з г льної м си ул мків проби. ік во, що крупноул мковий м тері л, зокрем , фр кція 40-10 мм, скл дений уже кільком пород ми - крім левролітів і пісковиків, тут є силіцити. силіцити прип д є близько $6 \%$ від з г льної кількості ул мків фр кції і 3 відсотковим вмістом вони є другою скл довою зерен фр кції. йбільше серед ул мків фр кції тр пляється левролітів, н які прип д є до $90 \%$ від з г льної кількості ул мків фр кції. ісковики є третьою скл довою, вони ст новлять до 4 \% від з г льної кількості ул мків фр кції.

от серед ул мків розміром пон д 40 мм тр пляються лише левроліти т пісковики, силіцитів нем . еред 15 зерен левролітів лише 10 ул мків зберегли первинну форму, решт були розл м ні ще під ч с відбору проби. ерев жн м с левролітових зерен м є розмір від 50 до 70 мм по довгій осі, дв ул мки - до 90 мм і лише один ул - 
мок досяг в 110 мм. обто домінують зерн г лечникової розмірності, тр пився лише один в лун.

обк $m$ ністю г лечниковий м тері л розрізу орг новичі 1 розподілився т к, як н ведено в т бл. 2.

блиця 2

л сифік ція левролітів розміром пон д 40 мм 3 ступенем обк т ності

\begin{tabular}{|c|c|c|c|c|c|c|}
\hline \multirow[b]{2}{*}{ 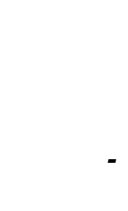 } & \multicolumn{2}{|c|}{ роб 1} & \multicolumn{2}{|c|}{ роб 2} & \multicolumn{2}{|c|}{ роб 3} \\
\hline & $\begin{array}{l}\text { ількість } \\
\text { ул мків }\end{array}$ & $\begin{array}{c}\text { коефіціент } \\
\text { обк т - } \\
\text { ності } \\
\text { проби }\end{array}$ & $\begin{array}{c}\text { кількість } \\
\text { ул мків }\end{array}$ & $\begin{array}{c}\text { коефіцієнт } \\
\text { обк m - } \\
\text { ності } \\
\text { проби }\end{array}$ & $\begin{array}{c}\text { кількість } \\
\text { ул мків }\end{array}$ & $\begin{array}{c}\text { коефіцієнт } \\
\text { обк т - } \\
\text { ності } \\
\text { проби }\end{array}$ \\
\hline 0 & - & \multirow{5}{*}{24} & - & \multirow{5}{*}{44} & - & \multirow{5}{*}{28} \\
\hline 1 & 2 & & 11 & & 1 & \\
\hline 2 & 2 & & 9 & & 3 & \\
\hline 3 & 6 & & 5 & & 7 & \\
\hline 4 & - & & - & & - & \\
\hline
\end{tabular}

проб х 1 т 3 домінують добре обк т ні зерн левролітів, менше середньо- т пог нообк т них зерен. окрем, у пробі 1 перев ж ють добре обк т ні левроліти, які предст влені шістьм зр зк ми. ещо менше (по дв ул мки) середньо- т пог нообк т них левролітів.

пробі 3 добре обк т них ул мків є сім зерен, середньообк т них - три, пог но обк т них - лише один ул мок.

бсолютно інший розподіл у пробі 2, у якій домінують пог но обк т ні ул мки, середньо- т , особливо, добре обк т ні ул мки м ють підпорядков не зн чення. ог но обк т них зерен левролітів виявлено 11, дещо менше (дев'ять зерен) - середньообк т них. йменшу групу (п'ять ул мків) формують добре обк т ні левроліти.

нші співвідношення є між проб ми, якщо порівнюв ти їх 3 коефіцієнтом обк т ності. йвищий коефіцієнт обк т ності (близько 44) прип д $є$ н ул мковий м тері л проби 2. уттєво (м йже вдвічі) нижчі коефіцієнти обк т ності прит м нні люві льному м тері лу проб 1 т 3,-відповідно, 24 т 28. кий ном льний, н перший погляд, х р ктер розподілу коефіцієнт обк т ності проб виник з вдяки великій кількості (дев'ять ул мків) середньообк т них зерен левролітів у пробі 2. е пр ктично повністю нівелює н дзвич йно високий вміст у цій же пробі пог нообк т них ул мків левролітів (11 зерен).

трибкоподібний х р ктер розподілу коефіцієнт обк т ності свідчить про мінливість умов ос дон гром дження в меж х окремих горизонтів лінз люві льної товщі розрізу.

ослідження гр війно-г лечникової товщі розрізу орг новичі 1 з свідчили, що більшість ул мків м є дископодібну і плоско-подовгув ту форму, які добре н д ються для з мірення їхньої імбрик ції, звідси - і відтворення н прямів тр нспортув ння ул мкового м тері лу (течії п леопотоків) [10, 17-19, 26-28]. мбрик цію ул мків ми 3 міряли в трьох горизонт льних інтерв л х люві льної товщі з потужністю інтерв лів 25-30 см (рис. 1).

одному інтерв лі з міряли зимути 27-110 дископодібних і плоско-видовжених ул мків розмір ми 25-30 мм по довгій осі. ути н хилів вимірюв них ул мків (поверх- 
ня $-\boldsymbol{b}$ ) головно не перевищув ли $35^{\circ}$. ільші кути спостеріг ли н йч стіше у вип дку конт ктової імбрик ції.

міри імбрик ції д ють не з вжди однозн чні результ ти, зокрем з міри 55 ул мків у н йвищому інтерв лі не виявили жодного перев жного н пряму імбрик ції, тобто ул мки н хилені рівномірно в усі н прями.

середньому інтерв лі досліджув ної люві льної товщі візу льно добре вир жен похил ш рув тість, що свідчить про н копичення ул мків н схилік н лу (русл ), бо н тому схилі міжрук вного остров , який обернений з течією п леопотоку. ут викон но 27 з мірів імбрик ції ул мків у меж х одного к н лу. міри виявили дв протилежно розт шов ні м ксимуми імбрик ції.

міри у нижньому горизонті люві льної товщі довели, що ул мки м ють імбрик цію в н прямі н північ-північний схід.

тже, у розрізі орг новичі 1, точніше, у доступній для вивчення ч стині розрізу, 3 фіксов но щон йменше три ет пи ос дон гром дження лювію, розділених двом ет п ми розмиву. і ет пи прочитуються як у текстурних елемент х товщі - м сивній текстурі внизу і лінзоподібній уверху, різних тип х ш рув тостей, т к і у змін х гр нулометричного скл ду лювію, обк т ності гр війно-г лечникового м тері лу, імбрик ції тощо. е д є підст ви вв ж ти, що люві льні відкл ди в розрізі орг новичі 1 репрезентують н копичення 6 г торук вної річки. окрем, нижня ч стин люві льної товщі н гром джув л сь під ч с повеней у субсередовищі головних русел 6 г торук вної річки. лювій був відкл дений у неглибоких і широких русл х бо н міжруслових люві льних відсип х (остров х) і згодом не був перероблений п леопотоком під ч с н ступних повеней.

ерхня ч стин люві льної п чки н копичув л сь у неглибоких і нешироких рук в х, н міжрук вних люві льних відсип х (остров х), неоднор зово з зн в л перероблення п леопотоком під ч с н ступних повеней.

риверт є ув гу і той ф кт, що у скл ді лювію домінують невеликі ул мки г лечникової т гр війної розмірностей з пр ктично, повної відсутності в лунів. е свідчить про незн чну тр нспортув льну зд тність потоку, м лий ухил річки.

петрогр фічному скл ді гр війно-г лечникових зерен розрізу орг новичі 1 домінують левроліти т пісковики, співвідношення яких по розрізу м ло змінюється. ретьою скл довою ул мкового м тері лу є силіцити, які тр пляються серед ул мків гр війної розмірності. ік во, що левроліти, пісковики є неміцними т одноч сно пог нобо середньообк т ними. е свідчить про близьке тр нспортув ння ул мкового м терілу, який, н н ш погляд, н дходив як з близько розт шов них рп т, т к і з ередК рп ття. н чн ч стин гр війно-г лечниково-в лунних зерен предст влен пород ми, які ми виявляли у виход х відкл дів б лицької форм ції с мбірської зони прогину [15].

пост ч ння ул мкового м тері лу з рп т свідчить і орієнт ція ул мків, точніше - відтворені н їхній підст ві н прями тр нспортув ння лювію. йімовірнішим н прямом течії п леопотоку і тр нспортув ння ул мків у р йоні розрізу орг новичі 1 був н прям, н ближений до н пряму південний з хід-північний схід, тобто від рп т н схід. ей н прям збіг ється із суч сним ухилом поверхні шостої тер си (поверхні оєвої), її цоколю в р йоні орг новичі- мбір.

дн к у розрізі орг новичі 1 вд лось докл дно опр цюв ти лише середню т верхню ч стини люві льної товщі. ї нижня ч стин, т кож конт кт 3 корінними відкл д ми не відслонений і не був про н лізов ним. ому викл дені вище рекон- 
струкції т інтерпрет ції середовищ люві льного ос дон гром дження н леж ть до з верш льних ет пів кумуляції люві льного гр війно-г лечникового м тері лу. мовірно, що під ч с ос дження верхньої ч стини лювію рельєф досліджув ного р йону був дуже плоским, з ухилом поверхні н північний схід.

1. ожик . . ресноводные моллюски позднего к йнозоя юг осточной вропы : в 2 ч. / . ожик - иев : огос, 2006. -280 с.

2. офштейн . . еотектонік і морфогенез ерхнього ридністров'я / . . офштейн. - иев : ид-во , 1962. - $131 \mathrm{c.}$

3. $p$ дзиньский. едиментология: пер. с пол. / . р дзиньский, . остецк я, . домский, . нруг; пер. изд. $\quad$. - . : едр , 1980. -640 с.

4. емедюк . . ревние поверхности выр внив ния кр инских рп т/ . . емедюк// еоморфология. - 1982. - № 3. - . 36-44.

5. емедюк . . оверхности выр внив ния кр инских рп т и их предгорий / . . емедюк // Studia Geomorphologica Carpatho-Balkanica. 1983. - Vol 16. - S. 3-14.

6. $р$ вчук . еоморфологія ередк рп ття / . р вчук. - ьвів : ерк тор, 1999. - 188 с. ( ельєф кр їни).

7. рохм ль . . естон хождения мелких млекопит ющих плейстоцен кр ины и сопредельных территорий : моногр фия / . . рохм ль, . . ековец; отв. ред. . . ожик . - иев : LAT \& K, 2010. - $300 \mathrm{c}$.

8. етодическое руководство по изучению и геологической съёмке четвертичных отложений / [под ред. . . ковлев ]. - . . осгеолтехизд т, 1955. - . 2. - 486 с.

9. етодическое руководство по изучению и геологической съёмке четвертичных отложений / [под ред. . . г дж нян, . . орисов, . . р йцев и др]. - . . едр , 1987. - 308 с.

10. ейнек .- . бст новки терригенного ос дкон копления (с р ссмотрением терригенных кл стических ос дков): пер. с нгл. / .- . ейнек, . . ингх; пер. . . милкстын, . . ит ров , . . ченской, . . ернов - ег рев , под ред. . . оченов . - . : едр , 1981. 439 с.

11. ухин . . сновы литологии / . . ухин. - . : остоптехизд т, 1953. -671 с.

12. цищин . т пи формув ння т геоморфологічн будов долини р. тривігор у меж $\mathrm{x}$ ередк рп ття / . цишин, . огуцький, . лотніков // існ. ьвів. ун-ту. ер. геогр. -2008. - ип. 35. - .348-360.

13. цишин . . етоди дослідження четвертинних відкл дів: н вч.-метод. посіб. [для студ. вищ. н вч. 3 кл.] / . . цишин, . . м митрук, . огуцький. - ьвів. ид вничий центр імені в н р нк , 2009. - 177 с.

14. цишин сновні ет пи верхньопліоцен-нижньоплейстоценового морфо-, літогенезу долини ністр у р йоні лицького ридністер'я / . цишин // існ. ьвів. ун-ту. ер. геогр. - 2010. ип. 38. - . 379-394.

15. цищин . еологічн будов дочетвертинних відкл дів північно-з хідної ч стини кр їнського ередк рп ття / . цишин, . огуцький, . омбель, . льшевськ - ейберт, . митрук, . лотніков // ляці лі перигляці л кр їнського ередк рп ття : зб. н ук. пр ць (до V укр їнсько-польського семін ру. мбір, 15-18 вересня 2011 р). - ьвів : імені в н р нк , 2011. - . .15-25.

16. цищин . т пи морфогенезу північно-з хідної ч стини долини ністр / . цишин, . огуцький, . олуб, . нчонт, . оменюк // ляці л і перигляці л кр їнського ередк рп ття : зб. н ук. пр ць (до $\mathrm{V}$ укр їнсько-польського семін ру. мбір, 15-18 вересня 2011 р). ьвів : імені в н р нк, 2011. - .26-61.

17. Gradzinski R. Wyró nianie i klasyfikacja kopalnych osadów rzecznych / R. Gradzinski // Postęry nauk geologicznych. - 1973. - № 5. - S. 57-112.

18. Jacyszyn A. Rekonstrukcja kierunku transportu utworów wirowych poziomu Łojowej w doline Dniestru k. Sambora na podstawie imbrykacji otoczaków / A. Jacyszyn, A. Bogucki, D. Olszewska- 
Nejbert, M. Bąbel, S. Waśkiw // ляці л і перигляці л кр їнського ередк рп ття: зб. н ук. пр ць (до V укр їнсько-польського семін ру. мбір, 15-18 вересня 2011 р). - ьвів : імені в н р нК , 2011. - .154-167.

19. Kauffman $M$. Cobble imbrication as a sensitive indicator of subtle local changes in river flow direction / M. Kauffman, D. Ritter // Geological Society of America. - 1981. - Vol. 9. - P. 299-302.

20. Nawara K. Transport i sedymentacja współczesnych wirów Dunajca i jego niektórych dopływów / K. Nawara // Prace museum Ziemi. - 1964.- № 6. - $121 \mathrm{~s}$.

21. Rutkowwski J. Badania uziarnienia osadów bardzo gruboziarnistych / J. Rutkowwski // Badania osadow czwartorzedowych. Wybrane metody i interpretacja wynikow. - Warszawa : Wydzial Geografii i Srudiow Regionalnych Uniwersytetu Warszawskiego, 1995. - S. 106-114.

22. Rutkowwski J. Badania petrograficzne wirów / J. Rutkowwski // Badania osadow czwartorzedowych. Wybrane metody i interpretacja wynikow. - Warszawa : Wydzial Geografii i Srudiow Regionalnych Uniwersytetu Warszawskiego, 1995. - S. 133-150.

23. Terpilowski S. Analiza sedymentologiczna osadów plejstoceńskich w stanowisku Torganowyczi 1 / S. Terpilowski, A. Godlewska, A. Bogucki, M. Łanczont, B. Holub, A. Jacyszyn, J. Kusiak, P. Mroczek, B. Woronko, P. Zieliński // ляці л і перигляці л кр їнського ередк рп ття : зб. н ук. пр ць (до V укр їнсько-польського семін ру. мбір, 15-18 вересня 2011 р). - ьвів : імені в н р нК , 2011.- .117-123.

24. Teisseyre H. Problemy morfologiczne wschodniego Podkarpacia / H. Teisseyre // Sprawozdania Polskiego Instytutu Geologicznego. - 1933. - T. 7. - Z. 3. - S. 421-454.

25. Teisseyre H. Czwartorzęd na predhorgy arkuszy Sambor i Dobromil / H. Teisseyre // Rocz. Pol. Tow. Geol. - 1938. - T. 13. - S. 31-81.

26. Teisseyre A. Uło enie otoczaków w osadach roztok na przykładzie koryt współczesnych i kopalnych karbońskich (niecka śródsudecka, Sudety Środkowe) / A. Teisseyre // Geologia Sudetica. - 1975. - Vol. 10. - № 1. - S. 47-58.

27. Unrug R. Wspolczesny transport i sedymentacja zwirow w doline Dunajca / R. Unrug // Acta Geologica Polonica. - 1957. - T. 7. - S. 217-257.

28. Wittenberg L. Structural Patterns in Coarse Gravel River Beds: Typology, Survey and Assessment of the Roles of Grain Size and River Regime / L. Wittenberg // Geografiska Annaler. - 2002. - Ser. A. Vol. 84. - №1. - P. 25-37. 


\title{
LITHOLOGICAL AND SEDIMENTOLOGICAL CHARACTERISTIC OF THE ALLUVIUM OF THE SIXTH TERRACE OF THE DNISTER RIVER (LOYEVA LEVEL) IN THE TORHANOVYCHI 1 SECTION
}

\author{
A. Yatsyshyn*, M. Bąbel**, D. Olszewska-Nejbert**, \\ A. Bogucki*, S. Vas'kiv* \\ *Ivan Franko National University of Lviv, \\ . Doroshenko St., 41, UA - 79000 Lviv, Ukraine \\ **Warsaw University, \\ wirki \& Wigury St., 93, 02-089 Warsaw, Poland
}

The main lithological characteristics of the alluvial sands, gravels and pebbly deposits in the particular layers of the six terrace of the Dnister River (the Loyeva level) near Sambir, Lviv oblast, west Ukraine, are given. The textural features of these beds, the granulometrical and petrographical composition of the alluvium, roundness of the gravelly and pebbly material, the orientation of pebbles (imbrication), and the other features are characterized. On the base of the obtained results of the lithological investigation the conditions of sedimentation of the alluvial sands, gravels and pebbly deposits of the six terrace of the Dnister River (the Loyeva layer) at the environs of Sambir are interpreted.

Key words: granulometric composition, petrographic composition, roundness, sorting, imbrication, braided channel, conditions of sedimentation.

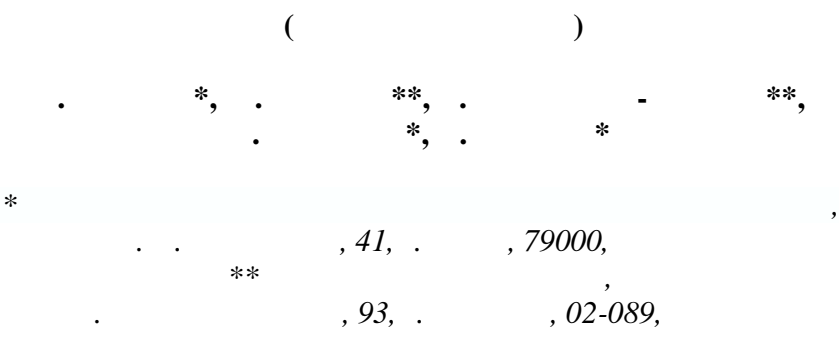

ро н лизиров но гл вные литологические х р ктеристики ллюви льных песч но-гр вийно-г лечниковых толщ шестой терр сы нестр (уровня оевой) вблизи г. мбор, ьвовской обл. х р ктеризов но: текстурные элементы толщ, гр нулометрический и петрогр фический сост в ллювия, ок т нность гр вийно-г лечникового м тери л, ориент ция г лечников и другое. основ нии полученных результ тов литологических исследов ний реконструиров но условия седимент ции ллюви льных песч но-гр вийно-г лечниковых толщ шестой терр сы нестр (уровня оевой) в р йоне г. мбор.

лючевые слов : гр нулометрический сост в, петрогр фический сост в, ок т нность, сортов нность, имбрик ция, многорук вное русло, условия ос дон копления. 